\title{
The Research on Evaluation and Management of China Forest Carbon Sinks from the Perspective of Economics
}

\author{
By Zhang Ying* \& Jiang Xiayu ${ }^{\dagger}$
}

\begin{abstract}
According to the latest forest resources inventory data, this paper establishes a physical and monetary accounts of forest carbon sinks, and an exploratory balance sheet for those from 2008 to 2013 in China, on the basis of national economic accounting theory and the latest System of National Accounts of United Nations. The results show that forest carbon stocks in physics have increased from 2008 to 2013, the average annual growth rate is about $2.51 \%$. Due to the decline of carbon sinks market price and the carbon sequestration in open forestland, the value of forest carbon stocks in monetary has decreased, by $0.37 \%$ per year. The built exploratory balance sheet of carbon sinks also shows that forest carbon assets are net outflows, which value 10.762 billion RMB yuan from 2008 to 2013. Based on the accounting results, the paper finally evaluates the economic significance of China's forest carbon sinks and gives some corresponding policy suggestions on its management. In addition, the paper points out that there are some errors in the balance sheet because of the statistical standards, classification and other reasons. The error rate is about $4.35 \%$, less than $5 \%$ of statistical requirements, which indicate that establishing forest carbon sinks accounts are possible, and accounting of values of forest carbon sinks according to the existing data is necessary in China.
\end{abstract}

Keywords: Accounts, Balance Sheet, Carbon Sinks, China, Forest Resources Value Accounting.

\section{Introduction}

Economic accounts not only reflect the economic situation at a certain point in time, but also provide indispensable continuous information for monitoring, analyzing and evaluating a certain amount of economic activity at different times (United Nations et al. 2012). Forest carbon sinks refers to the process of forest ecosystem absorbing $\mathrm{CO}_{2}$ from the atmosphere and fixing it in vegetation and soil, thereby reducing the concentration of $\mathrm{CO}_{2}$ in the atmosphere (Zhang et al. 2013). Although forest carbon sinks is a natural process, it is increasingly showing more economic characteristics as today's population, resources, and environmental issues become more prominent. Therefore, incorporating forest carbon sinks into the system of national accounts is necessary. It can reflect the relevant information of economic activities in the carbon sinks, and provide some information about the scale of assets, liabilities and wealth of an economy. Based on these information, it is of great significance to further explore the links between

${ }^{*}$ Professor, School of Economics \& Management, Beijing Forestry University, China.

${ }^{\dagger}$ Research Assistant, School of Economics \& Management, Beijing Forestry University, China. 
economic activities related to forest carbon sinks and other sectors at home and abroad, so as to comprehensively evaluate the contribution of forest carbon sinks to economic development, correctly understand the value of carbon sinks, promote the construction of ecological civilization and strengthen the management of resources, environment and ecosystem.

On the basis of the above conclusions, this paper tries to incorporate forest carbon sinks into the national economic accounting system, to reflect the relevant information of carbon sinks economic activities through the national accounts system, and to provide some information about the scale of their assets and liabilities related to an economy at a certain point in time. These information can help evaluate the value of Chinese forest carbon sinks from the perspective of economics.

Specifically, this paper tries to establish the physical and monetary accounts of forest carbon sinks and its balance sheet according to the System of National Accounts (SNA) in order to reflect the size of the impact of forest carbon sinks on the economy and their contribution to climate change, and also to provide some references for management decisions. In addition, the valuation methods of forest carbon sinks is also studied in this paper to make up the deficiencies of current relevant researches, as well as to help further systematic management of forest resources and environment in China.

\section{Literature Review}

In recent years, the research on forest carbon sinks mainly focuses on the establishment of carbon cycle model, the measurement of carbon stocks, the impact of carbon sinks on climate change, carbon sinks marketization and policies etc., but the research on establishment of balance sheet and forest carbon sinks accounting is less (Zhang et al. 2013).

In the mid and late 1960s, the International Biology Program (IBP) carried out which was the start of global carbon sinks research. In 1972, United Nations Educational Scientific and Cultural Organization (UNESCO) continued to study the programme and organized the Man and Biosphere Programme (MAB). After that, some European countries, Canada, the United States, the former Soviet Union, Brazil and other countries have conducted studies on the carbon balance of regional forest ecosystem and its relationship with the global carbon cycle. Wilson, Mitchell and other early researchers studied the economic accountting of forest carbon sinks. Johnson, Dixon, Brent Sohngen, Robert Mendelsohn, Roger A Sedjo, Neil Sampson and others also studied the economic value of forest carbon sinks (Dixon et al. 1994). Moreover, Brent Sohngen and Robert Mendelsohn evaluated the forest carbon sinks in America. Food and Agriculture Organization of the United Nations (FAO), Intergovernmental Panel on Climate Change of the United Nations (IPCC) and the United Nations Framework Convention on Climate Change (UNFCCC) also carried out econometric studies on carbon sinks in the global scope (Fang et al. 2001), but they have done little research on carbon sequestration from an economic perspectives. 
About the research of forest carbon sinks, he studied the impact of forests on the carbon cycle of the earth's climate system in 1993 (Zhang et al. 2013). In 2000, Fang carried out research on Chinese forest carbon sinks from the perspective of global ecology (Fang 2000). In 2003, Li et al. (2007) studied the role of forest carbon sinks in China from the perspective of global climate change, and did research on the position and countermeasures of China's forestry in the negotiation. In 2005, Wu, et al. (2006) discussed the carbon sinks issues of afforestation and reforestation under the Clean Development Mechanism. He et al. (2007) once again analyzed the current situation and potential of China's forest carbon sinks trading. Meanwhile, Zhang et al. (2010) conducted research on the role of forest carbon sinks in global climate negotiations. They established an econometric model of China's forest carbon sinks based on forest resources inventory data. In 2011 and 2012, they also using optimal control methods studied China's forest carbon sinks models (Gao et al. 2012), which lay a certain foundation for China's forest carbon sinks accounting and its account compilation.

In recent years, the research on forest carbon sinks has been extended to the trade measurement ( $\mathrm{Hu}$ and An 2014), supply-demand relationship (Yi et al. 2015), and the mechanism of market operation and other aspects (Tian 2016). We can see from the above study, since 2000, with the deepening of research on forest carbon sinks measurements, most of the research focus on the physical measurement, monetary measurement studies of less at home and abroad. Since 1973, China has conducted forest resource surveys every five years. At present, China has conducted eight forest resource surveys, namely forest resources inventory, they are the first forest resources inventory (1973-1976), the second forest resources inventory(1977-1981), the third (1984-1988), the fourth (19891993), the fifth (1994-1998), the sixth (1999-2003), the seventh (2004-2008), and the eighth (2009-2013) respectively, and accumulated a large amount of forest resources inventory data (Gao et al.2012). The statistics of forest resources and forest carbon sinks are gradually institutionalized in China. In addition, China has established nine pilot carbon trading markets in Beijing, Tianjin, Shanghai and other cities etc. Carbon sinks trading in China has been from the phase of theoretical research into the practical application.

These studies laid the foundation for the evaluation of forest carbon sinks from an economic perspective and integration of it into national economic accounts (United Nations et al. 2012). On the basis of related research, this paper tries to establish a physical and monetary accounts of forest carbon sinks and its balance sheet according to the center framework of System of Integrated Environmental and Economic Accounting (SEEA) of United Nations (United Nations et al. 2014) in order to evaluate the economic impact of it and further better manage forest resources (Zhao et al. 2008), as well as to provide some references for environmental economic management and policy making. 
Vol. 6, No. 2 Ying \& Xiayu: The Research on Evaluation and Management of China...

\section{Methodology}

Data

The main data of accounting of the forest carbon sinks come from the national forest resources statistics, China forest resources inventory, China forestry statistical yearbook, China statistical abstract (2008), China statistical yearbook (2015) and some related research reports. In particular, the data of forestland, stock and forest output mainly come from the national forest resources statistics. The data of annual increase and decrease in forest area, forest stock, GDP (Gross Domestic Product), forest investment, carbon emission, carbon sinks, etc. are derived from the China statistical abstract (2008), China statistical yearbook (2015) and China forestry statistical yearbook (2014) (China Foreign Exchange Trading Center 2016, Zhang et al. 2008). In addition, some data such as the trade volume of forest carbon sinks come from some related research reports (Zhang et al. 2008). The time scope of accounting is defined as the two periods of the two latest forest inventories, that is, from 2004 to 2013. Specifically, the seventh forest inventory from 2004 to 2008 and the eighth forest inventory from 2009 to 2013. The beginning year is 2008 , which is the last year of the seventh forest inventory and the end year is 2013, which is the last year of the eighth forest inventory in China. On the basis of the above data, the paper does some comparison studies between the physical and monetary accounts of the two forest resource inventories.

\section{Methods}

The account establishment method mainly adopts the System of National Accounts (SNA) method. That is, the SNA's accounting framework and economic data are further utilized to compile and express them according to the requirements of economic analysis, decision-making and policy making. The main goal of the account system method is to record the flow and stock of economic activities. The assets and liabilities held by institutions and departments at the beginning and end of the accounting period to reflect the stocks; a specific type of activity, such as the capital formation, distribution, redistribution, or use of production and income, reflects the data of flow. The account system law has the characteristics of comprehensiveness, consistency and integrity, and has become the standard guide and the main tool for many countries in the world to deal with the information of resources, environment and economic (see Figure 1). This has also become the standard of System of Environ-mental Economic Accounting (SEEA) framework recommended by the United Nations. Specifically, the paper mainly aims to do integrated survey and accounting to the forest carbon sinks in national economic activities, to record the stock and flow of the forest carbon sinks in economic activities, to establish the national balance sheets of it, and then to calculate some comprehensive index that reflect the national economy, such as the output of forest carbon sinks, GDP and so on. These can systematically reflect the flow of production and the stock of wealth in a certain period, and also can be helpful 
in understanding the impact of forest carbon sinks on the movement and structure of the national economy.

In addition, the establishment of the balance sheet mainly adopts the report form. The physical stock at the beginning and end of a period is calculated as follows, the closing stock $=$ the opening stock + the growth - the loss + the adjustment change (United Nations et al. 2014).

\section{Physical Accounting}

The establishment of the physical accounts of carbon sinks is mainly based on the data of forest resources inventory and the classification of forest stocks, and these accounts can reflect the stocks and changes of carbon sinks assets according to the compilation method of the asset and liability accounts. The asset items that reflect the classification of forest carbon sinks are shown on the left; the liabilities and net incomes that reflect changes in carbon sinks assets caused by economic activity are shown on the right. Due to the various classification of forest resources inventory, the opening and closing stock of carbon and the flow carbon sinks are shown above the account, which not only keeps the consistency between the economic accounting of forest carbon sinks and other assets and liabilities accounts of national economic accounting, but also saves the account space and guarantees the integrity of forest resources inventory data.

Figure 1. The Structure of the SEEA

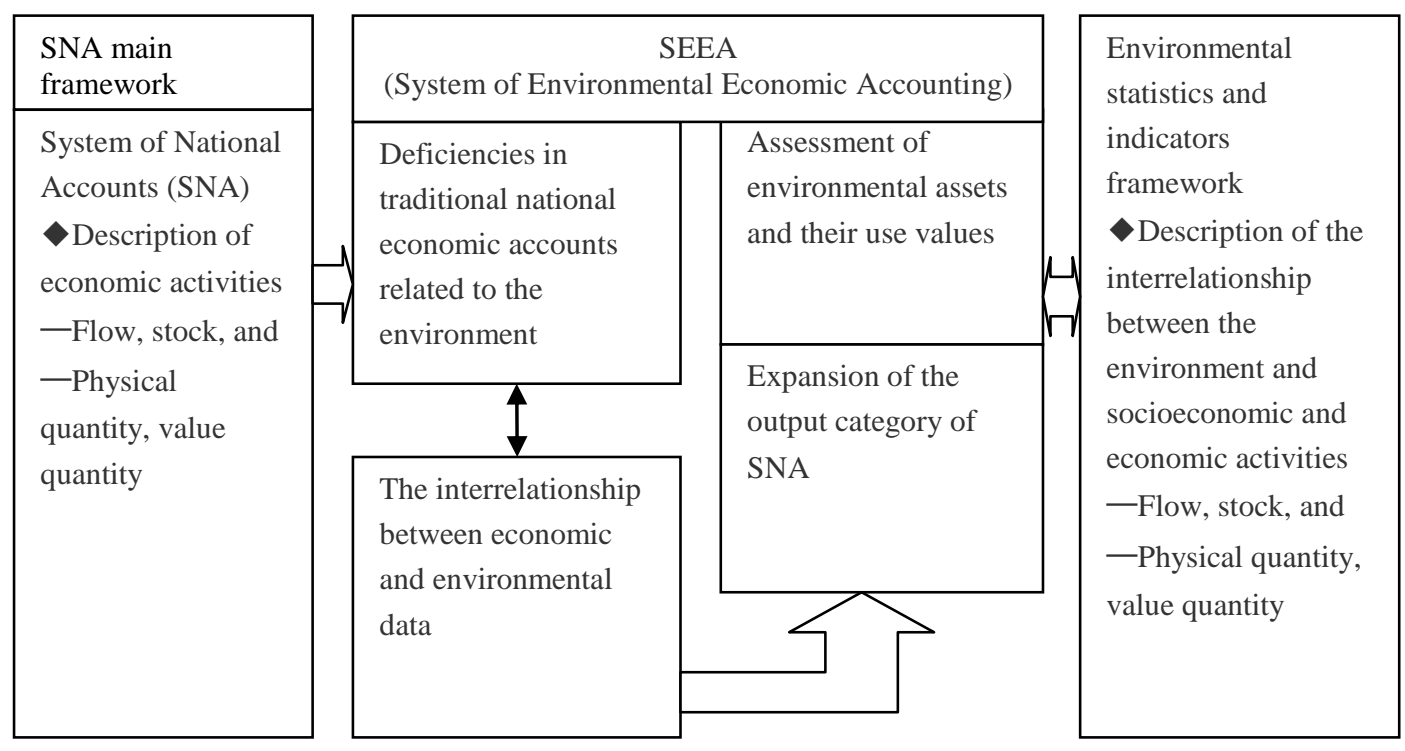

Source: United Nations (2018).

The physical quantity of carbon sinks is accounted for and calculated through the way that the stock is transformed, which should include carbon sinks of forests, understory vegetation and forest land. Carbon sinks of understory vegetation and forest land does not change much within a year. Therefore, the amount of carbon sinks in forests is only recorded and calculated in the account establishment and calculation, while the amount of carbon sinks of understory 
vegetation and woodland is not. The calculation formula adopts Li Shunlong's calculation model (Zhao et al. 2008). The model is:

1. $\quad C_{f}=V_{f} \cdot \delta \cdot \rho \cdot \gamma=V_{f} \cdot 1.90 \cdot 0.50 \cdot 0.50$

In which,

$C_{f}-$ Carbon sinks of forest, tons;

$\mathrm{V}_{f}$ - Forest stocks, $\mathrm{m}^{3}$;

$\delta$ - The transform coefficient between the forest stocks and the biomass, generally is 1.90 (dimensionless unit);

$\rho-$ The transform coefficient between the forest biomass and the biological dry weight, generally is 0.5 , tons $\bullet \mathrm{m}^{-3}$;

$\gamma$ - The transform coefficient between the biological dry weight and the carbon stocks, that is the carbon content rate, generally is 0.5 (dimensionless unit).

\section{$\underline{\text { Monetary Accounting }}$}

The monetary accounts of the forest carbon sinks corresponds to the physical accounts, recording the transactions related to the assets of carbon sinks and the transformation of carbon sinks capital which involves national wealth redistribution. The most important thing in the establishment of monetary accounts is evaluation of carbon sinks. Because evaluation is a bridge to monetization, it directly affects the value of the carbon sinks. According to the principle of national accounting, carbon sinks evaluation is mainly based on market price. Compared with foreign countries in the world, the reformation of the carbon tax and the mechanism of carbon sinks trading are not fully formed yet in China. Therefore, the evaluation of carbon sinks mainly adopts the net present value or the optimal valuation method which is close to the market price (Zhang et al. 2010).

According to the preliminary study, based on the national forest inventory data from 1990 to 2007, the author used the volume conversion method and the difference equation to study the change trend of forest carbon sinks in China, and calculated the optimal price of forest carbon sinks accounting (Zhang et al.2013).

In the process of calculating the optimal price of forest carbon sinks, some related researches show that China's total forest stocks can exceed 20 billion $\mathrm{m}^{3}$ by 2020, the total annual forest harvesting and utilization can reach more than 10 billion $\mathrm{m}^{3}$, converted into forest biological carbon stocks of 11.59 billion $\mathrm{t}$ according to calculation of volume conversion method (Yi et al. 2015),based on the forest inventory data and regression models in China from1990 to 2020, the equation of state forest carbon sinks accounting can be obtained:

2. $\left\{\begin{array}{c}C(k+1)=1.011 C(k) \\ C\left(k_{1990}\right)=117.44 \\ C(k) \geq 0,0 \leq L(k) \leq L(k)_{\max }=11.59\end{array}\right.$ 
In which: $\mathrm{C}(k)$ is the carbon storage of forest stocks in the year $\mathrm{k}, L(k)$ is the carbon storage of forest harvesting in the year $k, k$ is the year (Zhang et al. 2016).

In addition, some related studies also show that there is a certain relationship between the consumption of forest carbon stocks and economic development, especially the quadratic relationship between the carbon storage of forest harvesting and GDP in China (Yi et al. 2015). The regression equation further calculated is as follows:

$$
\text { 3. } \mathrm{GDP}=-7343.62 .440+3516775.471 L(k)-412558.604 L^{2}(k)
$$

In the above equation, we find that GDP is highly correlated with $L(k)$, the goodness of the regression equation fit $\mathrm{R}^{2}=0.998$, adjusted $\mathrm{R}^{2}=0.997, \mathrm{~F}$ value of the equation is 6581.48 , and the corresponding $\mathrm{P}$ value is 0.001 , indicating that the regression equation has statistical significance (Zhang et al. 2010).

If China's forest stocks is set at 20 billion $\mathrm{m}^{3}$ in 2020 (Fang 2000), the corresponding forest carbon stocks will be 231.71 billion $t$ according to the calculation of formula (1). So the shadow price of carbon sinks per ton in 2020 is calculated as 10.11 US dollars based on the minimum value of $L(k)$. In the same way, the shadow price of a ton of carbon sinks in 2020 can be calculated as $\$ 15.17$ based on the maximum value of $L(k)$, that is, the shadow price of forest carbon sinks in China is calculated at the interval of $\$ 10.11-\$ 15.17$ per ton, which is slightly higher than the current \$10-15/ton international carbon price (Pala Nazir et al. 2013). The result also reflects that the value change of China's forest carbon sinks is roughly consistent with the value change of the international carbon market.

\section{Results}

Physical Accounting Result

Based on the data of the seventh and eighth national forest resources inventory in China, the physical accounts of forest carbon sinks established. The carbon stocks and carbon sinks of China's forest in 2008 and 2013 are shown in Table 1.

In addition, there is a dispute over whether the carbon sinks of natural forest is included in the account. According to the SEEA 2003 published by the United Nations and other five departments (United Nations et al. 2014), the carbon sinks of natural forests is no different in supply and use from that of planted forests, and it also has distinct economic characteristics. Therefore, in the account establishment and accounting, the carbon sinks of natural forest and the planted forest are both included, so as to comprehensively reflect the contribution of China's forest carbon sinks to economic activities and the value of carbon sinks. 
Vol. 6, No. 2 Ying \& Xiayu: The Research on Evaluation and Management of China...

Table 1. Physical Accounts of Forest Carbon Sinks in China from 2008 to 2013

\begin{tabular}{|c|c|c|c|}
\hline Items & $\begin{array}{c}\text { Opening Stock } \\
(2008)\end{array}$ & $\begin{array}{c}\text { Changes } \\
(2008-2013)\end{array}$ & $\begin{array}{c}\text { Closing Stock } \\
(\mathbf{2 0 1 3})\end{array}$ \\
\hline Total carbon sinks (billion t) & 69.13 & 7.22 & 76.35 \\
\hline Arboreal forest & 63.47 & 6.73 & 70.20 \\
\hline Shelter forest & 34.91 & 2.84 & 37.75 \\
\hline Special-purpose forest & 8.29 & 2.01 & 10.31 \\
\hline Timber forest & 20.08 & 1.78 & 21.86 \\
\hline Firewood forest & 0.19 & 0.09 & 0.28 \\
\hline \multicolumn{4}{|l|}{ Economic forest } \\
\hline \multicolumn{4}{|l|}{ Bamboo forest } \\
\hline Open forestland & 0.54 & -0.04 & 0.50 \\
\hline \multicolumn{4}{|l|}{ Shrub land } \\
\hline \multicolumn{4}{|l|}{ Un-stocked forestland } \\
\hline Tree on the "Four Sides" & 1.58 & 0.32 & 1.90 \\
\hline Scattered tree & 3.54 & 0.21 & 3.75 \\
\hline In which : Natural forest & 54.63 & 4.20 & 58.83 \\
\hline arbor forest & 54.16 & 4.25 & 58.41 \\
\hline Shelter forest & 31.96 & 1.80 & 33.76 \\
\hline $\begin{array}{l}\text { Special-purpose } \\
\text { forest }\end{array}$ & 7.99 & 1.90 & 9.89 \\
\hline Timber forest & 14.04 & 0.44 & 14.49 \\
\hline Firewood forest & 0.17 & 0.10 & 0.26 \\
\hline \multicolumn{4}{|l|}{ Economic forest } \\
\hline \multicolumn{4}{|l|}{ Bamboo forest } \\
\hline Open forestland & 0.47 & -0.04 & 0.43 \\
\hline \multicolumn{4}{|l|}{ Shrub land } \\
\hline \multicolumn{4}{|l|}{$\begin{array}{l}\text { Un-stocked } \\
\text { forestland }\end{array}$} \\
\hline In which: Planted forest & 9.38 & 2.49 & 11.87 \\
\hline Arboreal forest & 9.31 & 2.48 & 11.80 \\
\hline Shelter forest & 2.95 & 1.04 & 3.99 \\
\hline $\begin{array}{l}\text { Special-purpose } \\
\text { forest }\end{array}$ & 0.31 & 0.11 & 0.41 \\
\hline Timber forest & 6.03 & 1.34 & 7.37 \\
\hline Firewood forest & 0.02 & 0.00 & 0.02 \\
\hline \multicolumn{4}{|l|}{ Economic forest } \\
\hline \multicolumn{4}{|l|}{ Bamboo forest } \\
\hline Open forestland & 0.07 & 0.01 & 0.08 \\
\hline Shrub land & & & \\
\hline $\begin{array}{l}\text { Un-stocked } \\
\text { forestland }\end{array}$ & & & \\
\hline
\end{tabular}

Source: Zhang et al. (2013).

As can be seen from the calculation results in Table 1, China's forest carbon stocks increased from 2008 to 2013. In 2008, forest carbon stocks were 69.13 billion $\mathrm{t}$, and it was 76.35 billion $\mathrm{t}$ in 2013 , with an annual growth rate of 2.51 percent. During the seventh and eighth forest inventory, the annual forest carbon 
sinks were about 245 million $\mathrm{t}$ and 306 million $\mathrm{t}$ respectively, with an average annual carbon sink increase of about 4.01 percent. The above calculation results are close to the data of 84.27 billion $t$ of total carbon stocks of forest vegetation in the eighth forest inventory that was published by the State Forestry Administration in 2016 in China (Zhang et al. 2016), indicating that the calculation results have accuracy and reliability.

In addition, during the accounting period, both the carbon stocks of natural forests and planted forests and the carbon stocks of all forests were increased. The growth rate of carbon stocks in planted forests is higher than that of natural forests. In the growth of forest sinks, the increase of planted forests is also higher than the natural forests, which is related to the continuous increase of the stock of planted forests in China. During the accounting period, only the carbon sinks of the open forest land in natural forests is reduced, with a decrease of 0.04 billion $t$, which is also related to the continuous increase of the planting area in China (Tian 2016, Zhao et al. 2008).

\section{Monetary Accounting Result}

In this paper, the upper limit of the optimal price of carbon sinks $\$ 15.17$ per ton is used. According to the exchange rate of RMB to US dollar in 2008 and 2013 (China Foreign Exchange Trade System 2016), the price of forest carbon sinks is calculated as 105.43 RMB yuan per ton in 2008 and 94.05RMB yuan per ton in 2013 separately.

In the same way, it is the same with the physical accounts, in the establishment of monetary account, the right side of the account records the asset items of forest carbon sinks, and the left side records the stocks of all carbon sinks assets which caused by economic activities and its changes in value from the beginning to the end during the accounting period. If the trading and flow of carbon sinks are positive, it indicates the net inflow of carbon sinks assets. On the contrary, it shows the net outflows of carbon sinks assets. Therefore, monetary accounts and accounting results of forest carbon sinks in 2008 and 2013 in China are shown in Table 2.

It can be seen from Table 2 that the value of forest carbon stocks in China in 2008 is 7288.5 billion RMB yuan, and is 7180.89 billion RMB yuan in 2013, with an average annual decrease of about $0.37 \%$. Forest carbon sinks assets also represented net outflows, with net outflows of about 107.62 billion RMB yuan. The main reasons for the decrease are the falling price of forest carbon sinks and the decrease of it in open forestland in physical quantity. 
Vol. 6, No. 2 Ying \& Xiayu: The Research on Evaluation and Management of China...

Table 2. Monetary Accounts of Forest Carbon Sinks in China from 2008 to 2013

\begin{tabular}{|c|c|c|c|}
\hline Items & $\begin{array}{c}\text { Opening Stock } \\
(2008)\end{array}$ & $\begin{array}{c}\text { Changes } \\
(2008-2013)\end{array}$ & $\begin{array}{c}\text { Closing Stock } \\
\text { (2013) }\end{array}$ \\
\hline $\begin{array}{l}\text { Total carbon sinks (billion } \\
\text { RMB yuan) }\end{array}$ & 7288.50 & -107.62 & 7180.89 \\
\hline Arboreal forest & 6691.89 & -89.51 & 6602.37 \\
\hline Shelter forest & 3680.99 & -130.25 & 3550.74 \\
\hline Special-purpose forest & 874.43 & 94.94 & 969.37 \\
\hline Timber forest & 2116.87 & -61.01 & 2055.87 \\
\hline Firewood forest & 19.59 & 6.81 & 26.40 \\
\hline \multicolumn{4}{|l|}{ Economic forest } \\
\hline \multicolumn{4}{|l|}{ Bamboo forest } \\
\hline Open forestland & 57.21 & -9.99 & 47.22 \\
\hline \multicolumn{4}{|l|}{ Shrub land } \\
\hline \multicolumn{4}{|l|}{ Un-stocked forestland } \\
\hline Tree on the "Four Sides" & 166.48 & 12.52 & 179.00 \\
\hline Scattered tree & 372.93 & -20.64 & 352.29 \\
\hline In which: Natural forest & 5759.64 & -226.64 & 5533.00 \\
\hline Arboreal forest & 5710.07 & -217.06 & 5493.01 \\
\hline Shelter forest & 3369.49 & -194.17 & 3175.31 \\
\hline $\begin{array}{l}\text { Special-purpose } \\
\text { forest }\end{array}$ & 842.26 & 88.12 & 930.37 \\
\hline Timber forest & 1480.62 & -118.06 & 1362.56 \\
\hline Firewood forest & 17.71 & 7.06 & 24.77 \\
\hline \multicolumn{4}{|l|}{ Economic forest } \\
\hline \multicolumn{4}{|l|}{ Bamboo forest } \\
\hline Open forestland & 49.57 & -9.58 & 39.99 \\
\hline \multicolumn{4}{|l|}{ Shrub land } \\
\hline \multicolumn{4}{|l|}{$\begin{array}{l}\text { Un-stocked } \\
\text { forestland }\end{array}$} \\
\hline In which: Planted forest & 989.46 & 127.13 & 1116.59 \\
\hline Arboreal forest & 981.82 & 127.55 & 1109.36 \\
\hline Shelter forest & 311.50 & 63.92 & 375.43 \\
\hline $\begin{array}{l}\text { Special-purpose } \\
\text { forest }\end{array}$ & 32.18 & 6.82 & 38.99 \\
\hline Timber forest & 636.25 & 57.05 & 693.31 \\
\hline Firewood forest & 1.88 & -0.25 & 1.63 \\
\hline \multicolumn{4}{|l|}{ Economic forest } \\
\hline \multicolumn{4}{|l|}{ Bamboo forest } \\
\hline Open forestland & 7.64 & -0.41 & 7.23 \\
\hline \multicolumn{4}{|l|}{ Shrub land } \\
\hline $\begin{array}{l}\text { Un-stocked } \\
\text { forestland }\end{array}$ & & & \\
\hline
\end{tabular}

Source: Zhang et al. (2016). 


\section{Establishment of Balance Sheet}

The balance sheet of forest carbon sinks is established in a form of a report. Table 3 is the balance sheet which was established under the assumption that current forest carbon sinks assets do not have a lag effect on other carbon sinks assets. In the balance sheet, the asset items are divided into natural forests, planted forests and other forest resources according to the forest types in forest resources inventory; the liability items, i.e., reduction of forest resources, include logging and natural depletion and losses caused by natural disasters, etc.; the net asset item, opening stocks of forest carbon sinks assets \pm changes of assets or liability=closing stocks of net assets) (Zhang et al. 2016). On the basis of above, the balance sheet is established shown in Table 3.

Table 3. The Balance Sheet of Forest Carbon Sinks in China from 2008 to 2013

\begin{tabular}{|l|c|c|c|}
\hline Items & $\begin{array}{c}\text { Opening Stock } \\
\mathbf{( 2 0 0 8 )}\end{array}$ & $\begin{array}{c}\text { Changes } \\
(\mathbf{2 0 0 8 - 2 0 1 3})\end{array}$ & $\begin{array}{c}\text { Closing Stock } \\
\mathbf{( 2 0 1 3 )}\end{array}$ \\
\hline Assets(billion RMB yuan) & & & \\
\hline Natural forest & 5759.64 & & \\
\hline Planted forest & 989.46 & & \\
\hline $\begin{array}{l}\text { Other assets of forest carbon } \\
\text { sinks }\end{array}$ & 539.40 & & \\
\hline Total & 7288.50 & 1702.02 & \\
\hline Liabilities(billion RMB yuan) & & & \\
\hline Forest harvesting & & -875.14 & \\
\hline Natural mortality & & -263.32 & \\
\hline Losses of natural disaster & & -358.46 & \\
\hline Total & & -1496.92 & \\
\hline Net asset & & & 7493.60 \\
\hline Actual net asset & & & 312.71 \\
\hline Error & & & 4.35 \\
\hline Rate of error $(\%)$ & & & \\
\hline
\end{tabular}

Source: CIConsulting (2018).

In Table 3:

Opening stocks: It is mainly based on the data of the seventh forest resources inventory, and is calculated according to the formula (1), Table 1 and Table 2.

Changes: According to the data of the seventh and eighth forest resources inventory and the average annual growth and consumption of all kinds of trees, it was obtained through the calculation according to Table 1 and Table 2.

Natural disasters: According to different leading factors of forest disasters, forest disasters can be divided into forest fires, forest diseases caused by insects or rodents and other disasters. The forest disasters can also be divided into three grades: light, medium and heavy according to the proportion of the number of dead trees. In the study, the loss of carbon 
sinks induced by natural disaster was calculated according to the disaster area and the stock per unit area of the three grades (Zhang et al. 2008, Pala Nazir et al. 2013).

Net assets: Net assets = opening stocks + current growth - deforestation natural mortality - losses of natural disaster.

$>$ Actual net assets: It is mainly based on the stand volume data of the eighth forest resources inventory, and is calculated according to the formula (1), Table 1 and Table 2.

Error: The difference between net assets and actual net assets caused by changes in statistical caliber and standard. The error of this accounting is 312.71 billion RMB yuan, and the error rate is $4.35 \%$, which is less than the 5\% error that required by statistical calculation (Pala Nazir et al. 2013). So the result is acceptable, and the results show that the balance sheet of carbon sinks established is feasible.

\section{Discussion}

Based on the above results, some discussions are raised. The price of carbon sinks is the expression of its values. Therefore, the price directly affects the estimated value of carbon sinks. At present, most of international carbon sinks value accounting adopts market value method and the net present value method. That is, the market value method is the direct method of carbon sinks trading in the market. Currently, since 2013, there are 9 carbon sinks trading markets in China, and the average trading price of $\mathrm{CO}_{2}$ per ton is about 20 to $30 \mathrm{RMB}$ yuan (CIConsulting 2018). Therefore, it is a challenge for China's carbon sinks trading market to integrate with the international carbon trading market and keep the carbon exchange price consistent. In addition, how to determine a standard forest carbon sinks valuation method is another challenge for China's carbon sinks market.

Carbon stocks and flows accounting are necessary. Forest carbon stocks accounting reflect the wealth status of carbon sinks capital, and flows accounting reflects production status of it in a country. Both of them reflect different aspects of carbon sinks capital. The main purpose of carbon sinks evaluation is to reflect the wealth and production levels of forest carbon sinks to be better management carbon sinks market in China. Therefore, both are indispensable and cannot be biased, and should be accounting together.

Similarly, in forest carbon sinks accounting, the loss due to economic reasons and natural disasters should be distinguished. Because the loss of economic reasons can be taken into the System of National Accounts (SNA), natural disasters cannot be from an economic point of view (Stephen 1992). This should be given sufficient attention in future forest carbon sinks evaluation and accounting. In current carbon sinks accounting in China, there is no distinction between the loss caused by natural disasters and economic activities, which is not in line with the principle of national economic accounting and should be corrected. 


\section{Conclusions}

Through the forest carbon sinks accounting and the balance sheet established from 2008 to 2013 in China, conclusions can be drawn. It is feasible and possible to establish the account for economic accounting of forest carbon sinks based on existing data and research results. In particular, United Nations et al. five departments published SEEA, provides a standard basis and technical support for the economic accounting of forest carbon sinks. The data of forest resources inventory and other forestry statistics also provide an important basis for forest carbon sinks accounting. In addition, some relevant researches in this field also make the accounting of forest carbon sinks possible. Therefore, it is proposed that, it is necessary to bring forest carbon sinks into the statistics of natural resources and environment to fully reflect the value of forest resources and the contribution of forests to mitigate of climate change from the perspective of economics.

From 2008 to 2013, the total physical stocks of forest carbon sinks in China were constantly increasing, with an increase of 722 million t. It indicates that the role of forests in climate change is increasing. The monetary accounting of carbon sinks shows that the value of forest carbon stocks in China is 7288.5 billion RMB yuan in 2008, and is 7180.89 billion RMB yuan in 2013, with an average annual decrease of about $0.37 \%$. Forest carbon sinks assets also represented net outflows, with net outflows of about 107.62 billion RMB yuan. The main reasons for the decrease are the falling price of forest carbon sinks and the decrease of carbon sinks in open forestland. Therefore, the value of forest carbon sinks in China is not simply related to the physical amount of carbon sinks, but also affected by the changes in the market price of it at home and abroad. It shows that in the management of forest carbon sinks, the change of the price should also be paid attention to.

In the establishment of balance sheet of forest carbon sinks, net assets = opening stock + current growth - deforestation - natural mortality - losses of natural disaster. However, the calculation error can be caused by the changes of statistical caliber, method, standard and classification during the forest resources inventory. In the period from 2008 to 2013, the error of forest carbon sink was 312.71 billion RMB yuan, and the error rate was $4.35 \%$, which less than $5 \%$ of the accepted statistical error. It shows that it is feasible to compile the balance sheet of forest carbon sinks and it also provides a reference for establishing balance sheets of other resources although forest carbon sinks are non-financial assets.

It is reported that the trading volume of global forest carbon sinks in 2013 has passed 10 billion dollars (Hu and An 2014), which is very meaningful in the development of the global forest carbon market. At present, the average annual trade volume of forest carbon sinks is relatively low in China. The result of calculation shows that annual average reduction of carbon sinks in China is about $0.37 \%$. Most of forest carbon sinks are not traded. It indicates that forest carbon sinks in China still have a huge trade potential. Therefore, this problem should be considered in the macroeconomic policy-making in the future to promote the development of China's carbon sinks market. 
Vol. 6, No. 2 Ying \& Xiayu: The Research on Evaluation and Management of China...

The study also serves to gain a better understanding of the current status of evaluation and management of China forest carbon sinks. However, there are also obvious limitations in the research, the data on forest resource surveys should be updated until now. This discrepancy may be due to the fact that the inventory of forest resources is carried out every five years in China. In addition, the technology of the establishment of balance sheet of forest carbon sinks is not very mature and is still under development and improvement, which is also the development direction of future study. Moreover, the compilation of forest carbon sinks accounts at the national level requires a large amount of resource and environmental statistics to support, which also needs to be improved in the future.

\section{References}

China Foreign Exchange Trading Center (2016) Historical query of RMB monthly average exchange rate (2016/01/04). DOI=http://www.Chinamoney.com.cn/fe/ Chamel/1738.

CIConsulting (2018) China carbon trading market in-depth research and investment prospects forecast report from 2018 to 2022 (2018/12/28). DOI=http://www.ocn. com.cn/reports/1395tanjiaoyishichang.shtml.

Dixon RK, Solomon AM, Brown S, Houghton RA, Trexier, MC, Wisniewski J (1994) Carbon pools and flux of global forest ecosystems. Science 263(5144): 185-190.

Fang JY (2000) Forest carbon pools in the middle and high latitudes of northern latitudes may be much smaller than currently estimated plants. Acta Ecologica Sinica 24(5): 635-38.

Fang JY, Chen AP, Peng CH, Zhao SQ, Ci LJ (2001) Changes in forest biomass carbon storage in China between 1949 and 1998. Science 292(5525): 2320-2322.

Gao MX, Zhang Y, Xu J (2012) The Analysis on Economic Accounting and Econometric of Comprehensive Environmental - From International Experience to Chinese Practice. Economic Science Press, Beijing.

He Y, Zhang XQ, Liu YX (2007) Status and potential of China's forest carbon sinks trading market. Forestry Science (7): 106-111.

Hu JB, An Z (2014) The study on measurement of forest carbon sink trade - a case study of Guizhou. Ecological Economy 30(12): 78-83.

Li NY, Xu ZH, Wang CF (2007) The selection and evaluation for priority development region of the project that related to carbon sink of afforestation and reforestation in China. Forestry Science (7): 5-9.

Pala Nazir A, Negi AK, Yogesh G, Showkat A, Vikrant KK, Todaria NP (2013) Carbon stock estimation for tree species of Sem Mukhem sacred forest in Garhwal Himalaya, India. Journal of Forestry Research 24(3):457-460.

Stephen DC (1992) Introduction to Economics. New York: Harper Perennial.

Tian Q (2016) Establishment of index of forest carbon sink market operation mechanism. Beijing Agriculture (4): 104-105.

United Nations, the International Monetary Fund, the World Bank, the Organization for Economic Co-operation and Development and the Statistical Office of the European Communities (2012) 2008 National Accounts System. Department of National accounts, National Bureau of Statistics of China, Institute of National Accounts of Renmin University of China, China Statistics Press, Beijing.

United Nations, the International Monetary Fund, the World Bank, the Organization for Economic Co-operation and Development and the Statistical Office of the European 
Communities (2014) System of Environmental Economic Accounting 2012 -- Central Framework. United Nations, New York.

United Nations (2018) Global Assessment of Environmental-Economic Accounting (2018/03/06). DOI=https://unstats.un.org/unsd/statcom/49th-session/documents/BGItem3h-2017-Global-Assessment-of-Environmental-Economic-Accounting-E.pdf.

Wu SH, Zhang XQ, Li JQ (2006) The analysis of leakage problems of CDM forestry carbon sink project. Forestry Science 32(2): 98-104.

Yi SH, Zhou WP, Ding Y (2015) Study on the supply-demand relationship andit's optimization of forest carbon sink market in Hunan province. Journal of Central South University of Forestry and Technology 35(1): 140-144.

Zhang Y, Hou YZ, Wei XZ (2008) Research on forest green accounting in Beijing. Journal of Beijing Forestry University 30(1): 232-237.

Zhang Y, Chen JC, Hu MX, Offer A (2016) Valuation of forest carbon sinks in China within the framework of the system of national accounts. Journal of Forestry Research 27(6): 1321-1328.

Zhang Y, Zhou X, Qin QF, Chen K (2013) The research on the accounting of China forest carbon sinks. Journal of Beijing Forestry University 35(6): 128-135.

Zhang WC, Tian J, Wang DM, Ding GD, Meng DX (2007) The research on forest carbon sink based on the negotiation of global climate change. Forestry Survey Planning 32(5): 18-22.

Zhang Y, Wu LL, Su F, Yang ZG (2010) The research on the accounting model of China forest carbon sinks. Journal of Beijing Forestry University 32(2): 194-200.

Zhao L, Yin MF, Chen XF (2008) An overview of measurement methods and research status of forest carbon sink. Journal of Northwest Forestry University (1): 59-63. 
